DOI: 10.5937/MegRev2004141V

Review Scientific Article

Received 03.05.2020.

Approved 12.07.2020

\title{
ECONOMIC RELATIONS BETWEEN BULGARIA AND SERBIA: CURRENT STATE AND OPPORTUNITIES ${ }^{* * * *}$
}

\begin{abstract}
The main goal of this paper is to make a survey of the current state of the economic relations between Bulgaria and Serbia and to outline some recommendations for their future development. The analytical framework is based on a desk research of the economic cooperation between both countries and a study of several European projects in which they participate. Statistical data and information from official documents of the governments of Bulgaria and Serbia, as well as documents of the European Union have been used. The author does not aim to make just a comparative analysis but rather to look for the points of intersection of the mutual interests of both countries. The findings of the research enable the evaluation of the depth of economic cooperation between Bulgaria and Serbia and give grounds for conclusions about the prospects for expanding of their economic ties.
\end{abstract}

Key words: Bulgaria, Serbia, economic cooperation, foreign trade, regional projects

\footnotetext{
* University for National and World Economy, Sofia, Alfa BK University, Belgrade; antoaneta.vassileva@alfa.edu.rs

** University Union Nikola Tesla, Belgrade; mira.stev@mts.rs

*** Alfa BK University, Belgrade; milica.simic@alfa.edu.rs

**** Ovaj rad je napisan u okviru trogodišnjeg Projekta Pravnog fakulteta Megatrend Univerziteta, Beograd, broj: 2044/20 od 01.10.2020. pod nazivom „Bezbednosni izazovi savremenog društva" (FPBISD).
} 


\section{Introduction}

Bulgaria and Serbia are neighboring countries similar in terms of territory and population, language and religion as well as historical, socio-political and economic development. Bulgaria is a member of the European Union (EU) since 2007 while Serbia, which has lived through severe military cataclysms and economic sanctions in the recent decades, is in a process of accession to the EU.

Both countries have a communist past whose negative consequences they are overcoming in their own way. The government of Bulgaria undertook a number of structural reforms in the 1990s to move from a centralized, planned economy to a more liberal, market-driven economy. These reforms included privatization of state-owned enterprises, liberalization of trade, strengthening of the tax system - changes that initially caused some painful hardships, but later helped to encourage economic growth. Being a member of the WTO since 1996 and joining NATO in 2004, Bulgaria managed to move gradually away from the dependence on markets of the former Comecon countries redirecting its foreign trade to the EU and attracting substantial foreign investments.

Serbia has a transitional economy largely dominated by market forces, but the state sector remains significant in certain areas. The economy relies on manufacturing and exports, driven largely by foreign investments. Serbia has made progress in trade liberalization, enterprise restructuring and privatization, but many large enterprises - including the power utilities, telecommunications company, natural gas company and others, still remain state-owned. The country has made some progress towards EU membership. In January 2014, Serbia's EU accession talks officially started, so half of the negotiation chapters out of total 35 have been opened, of which 2 chapters have already been provisionally closed ${ }^{1}$. A credible enlargement perspective of the EU supporting the progress along the European path of Serbia might be the Strategy for the Western Balkans adopted by the European Commission (EC) in February, 2018, where concrete actions and EUR 1.07 billion of pre-accession assistance have been foreseen. Another integration move of Serbia is the signing of an Agreement for a Free Trade Zone with the Eurasian Economic Union in 2019. Balancing between two geopolitical concepts the country is trying to turn into a bridge between Europe and Euroasia ${ }^{2}$.

Serbia's negotiations with the WTO are advanced, with the country's complete ban on the trade and cultivation of agricultural biotechnology products representing the primary remaining obstacle to accession. Serbia maintains a

1 “Tenth Meeting of the Accession Conference with Serbia at Ministerial level, Brussels, 27 June 2019", European Council, https://www.consilium.europa.eu/en/press/press-releases/2019/06/27/tenth-meeting-of-the-accession-conference-with-serbia-at-ministerial-level-brussels-27-june-2019/

2 Лисоволик Ярослав, Чимирис Екатерина (2016): Сербия - ЕАЭС: перспективы интеграции в рамках зоны свободной торговли. Рабочая тетрадь № 37/2016/, Российский совет по международным делам, Москва, 20 
three-year Stand-by Arrangement with the IMF worth approximately USD 1.3 billion that was scheduled to end in February, 2018. In July, 2018, the Executive Board of the IMF approved a new 30-month Policy Coordination Instrument for Serbia. The government has shown progress implementing economic reforms, such as fiscal consolidation, privatization, and reducing public spending ${ }^{3}$.

\section{Methodology}

The purpose of this paper is to study the current state of the mutual economic relations of two neighboring countries and to reveal the opportunities for their future development. Taking into account the similarities and the differences between them, it proves the idea that cooperation can be more beneficial when the countries cope with identical economic challenges. The analysis below integrates a research of the mutual exchange of goods and services between Bulgaria and Serbia and a survey of some new forms of cooperation in which both countries participate. The authors try to fill the knowledge gap due to the lack of recent publications on the topic.

Methodology is based on a set of general and specific methods of scientific knowledge such as analysis and synthesis, abstraction and generalization, induction and deduction, statistical methods as well as comparative analysis. Main sources of information are normative documents, documents of the EU, academic literature, articles, reports of the WEF, UNCTAD, the World Bank data base, the CIA World factbook, the UN COMTRADE data base on international trade, etc.

\section{Bilateral Economic Relations}

As stated above, Bulgaria and Serbia have undergone significant transformations over the past three decades and face a lot of similar challenges as a part of the globalized world ${ }^{4}$. According to the Global Competitiveness Report 2018 of the World Economic Forum Bulgaria ranks $51^{\text {st }}$ out of 140 countries in the world, while Serbia occupies the $65^{\text {th }}$ position ${ }^{5}$. The Global Competitiveness Index 4.0 measures national competitiveness - defined as the set of institutions, policies and factors that determine the level of productivity. The average salary

https://www.cia.gov/library/publications/the-world-factbook/geos/ri.html, (26.09.2019)

Vassileva Antoaneta,' Talović R. Violeta., Stojadinović Miša (2018): Geopolitical and Economic Challenges of the Globalized World, Lambert Academic Publishing, Saarbrucken, 274

5 The Global Competitiveness Report (2018), WEF, https://www.weforum.org/reports/theglobal-competitveness-report-2018 
per month in Bulgaria is EUR 626 (BGN 1 253) ${ }^{6}$, which makes it the poorest country in the EU. The average salary in Serbia is EUR 454 (RSD 53 633) ${ }^{7}$. The inflation rate in Bulgaria is $2.8 \%$ (2018) while in Serbia $-2.0 \%$ for the same year. At the same time population below poverty in Bulgaria is $22.0 \%$ (2017). In Serbia population below poverty line is $7.3 \%$ (2017), which means that Serbia relies more on social policy than Bulgaria, which is due to the price ratio and the services that are still free of charge like education, health care and others. The more communitarian type of economy allows the government to subsidize some state-owned enterprises, and to maintain the prices of the most essential commodities comparatively low. Bulgaria has reached a good level of unemployment rate of $5.3 \%$ (2018) unlike Serbia which has an unemployment rate equal to 13.5 $\%(2018)^{8}$.

The GDP of Bulgaria is USD 65 billion in 2018 according to the World Bank database $^{9}$, (see Figure 1). Its present composition by sector of origin consists of agriculture $4.3 \%$, industry $28 \%$ and services $67.4 \%(2017)^{10}$. The main industries contributing to the GDP, are connected with the production of electricity, gas, water, food, beverages, tobacco, machinery and equipment, automotive parts, base metals, chemical products, coke, refined petroleum, nuclear fuel as well as outsourcing. Bulgaria's most famous agricultural products are vegetables, fruits, tobacco, wine, wheat, barley, sunflower, sugar beets and livestock.

Tracking statistical data referring to the volume of exports, imports, revenues from tourism and merchandise trade as a part of GDP shows that Bulgaria has had a more open economy than Serbia throughout the years. According to the World Bank data base the total merchandise export of Bulgaria in 2018 is equal to USD 33.2 billion and merchandise trade comprises $109 \%$ of the GDP. The main focus in export is put on clothing, footwear, iron and steel, machinery and equipment, fuels, agriculture, tobacco, IT components. The biggest importer of Bulgarian goods is Germany $13.5 \%$, followed by Italy $8.3 \%$, Romania $8.2 \%$, Turkey 7.7\%, Greece 6.5\% and France $4.1 \%(2017)^{11}$.

The import amounts to USD 37.9 billion (2018). It includes mainly machinery and equipment, metals and ores, chemicals and plastics, fuels, minerals and raw materials. The trading partners with largest contribution to the import are Germany $12.3 \%$, followed by Russia $10.3 \%$, Italy $7.3 \%$, Romania $7.1 \%$, Turkey $6.2 \%$, Spain 5.3 and Greece $4.4 \%$ (2017). Bulgaria is heavily reliant on energy imports from Russia, a potential vulnerability, and is a participant in EU-backed efforts to diversify regional natural gas supplies.

\footnotetext{
6 https//tradingeconomics.com/bulgaria, (27.09.2019)

$7 \mathrm{http} /$ tradingeconomics.com/serbia, (27.09.2019)

8 The World bank data base, WB, data.worldbank.org, (27.09.2019)

9 Ibid.

10 Ibid.

$11 \mathrm{https//tradingeconomics.com/Bulgaria,} \mathrm{(27.09.2019)}$
} 
Although based on services, the reliance of Bulgarian economy on energy imports and foreign demand for its exports makes its growth sensitive to external market conditions. In recent years, strong domestic demand, combined with low international energy prices, have determined Bulgaria's economic growth of $3.1 \%$ (2018). The economy of Serbia relies on manufacturing end exports, driven largely by foreign investment, which lead to a growth of $4.3 \%(2018)^{12}$.

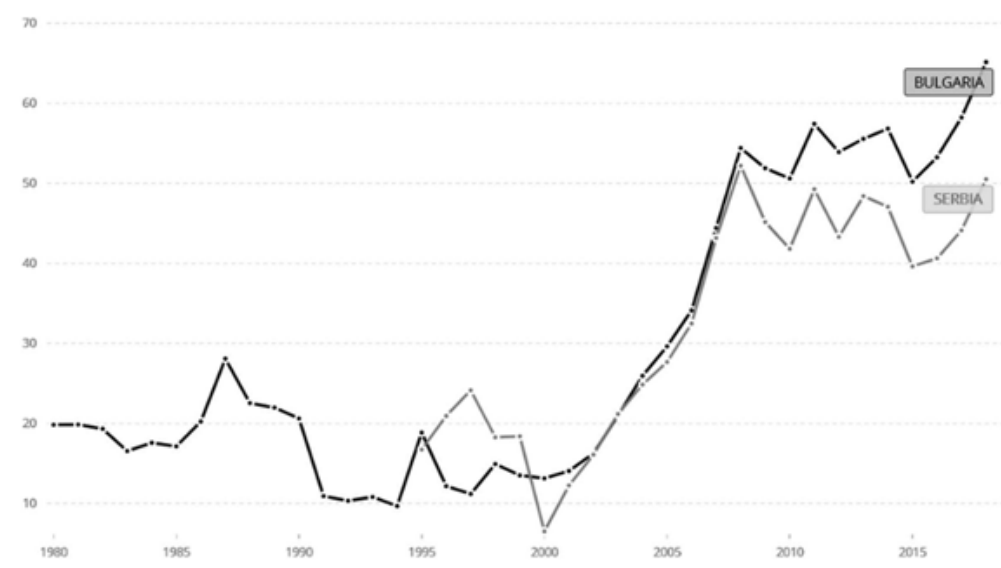

Source: The World bank data base, WB, data.worldbank.org, (26.09.2019)

Figure 1. GDP of Bulgaria and Serbia (current USD) billion

The GDP of Serbia is USD 50.5 billion (see Figure 1). Its structure, which is agriculture $9.8 \%$, industry $41.1 \%$, services $49.1 \%$ (2017), is rather balanced. The main industrial sectors are those connected with the production of automobiles, base metals, furniture, food processing, machinery, chemicals, sugar, tires, clothes, pharmaceuticals. Regarding the agriculture - wheat, maize, sunflower, sugar beets, grapes/wine, fruits (raspberries, apples, sour cherries), vegetables (tomatoes, peppers, potatoes), beef, pork, and meat products, milk and dairy products are very important items ${ }^{13}$.

The total merchandise export of Serbia is equal to USD 19.2 billion (2018), merchandise trade is worth of $89.3 \%$ of the GDP. ${ }^{14}$

It includes automobiles, iron and steel, rubber, clothes, wheat, fruit and vegetables, nonferrous metals, electric appliances, metal products, weapons and ammunition. The main partners in the export transactions are companies from Italy $12.3 \%$, Germany $12 \%$, Bosnia and Herzegovina $7.9 \%$, Romania $5.9 \%$, Russia $5.3 \%(2018){ }^{15}$

The World bank data base, WB, data.worldbank.org, (26.09.2019)

13 https://data.worldbank.org/indicator/NY.GDP.MKTP.KD.ZG?locations=BG-RS, (27.09.2019)

14 Ibid.

$15 \mathrm{http} / /$ tradingeconomics.com/Serbia, (27.09.2019) 
The import amounts to USD 25.9 billion (2018). The import items cover machinery and transport equipment, fuels and lubricants, manufactured goods, chemicals, food and live animals and raw materials. The countries that have the biggest share in the import of Serbia are Germany $13.4 \%$, Italy $9.4 \%$, China $8.4 \%$, Russia 7.9\%, Hungary 4.8\% and Turkey $3.8 \%$ (2018). ${ }^{16}$

The statistical data show that Bulgaria and Serbia have been traditional economic partners for many years (Figure 2, Figure 3). According to data of the Statistical Office of the Republic of Serbia the most important trade partners of Serbia in 2018 were the EU countries with $63 \%$ of the total foreign trade. There are only nine EU countries with which Serbia doesn't have negative trade balance. With two of them Serbia has particularly intensive commodity exchange and those are Rumania with EUR 970 million, and Bulgaria with EUR 614 million, which makes up around $10 \%$ of the total Serbian export.

According to the Ministry of Foreign Affairs of Serbia Bulgaria is one of its most important trading partners ${ }^{17}$. As it has been reported at the session of the Joint Serbia-Bulgaria Intergovernmental Committee on Economic Cooperation which was held in Belgrade in 2017, trade in goods reached a record high level of EUR 1 billion (Serbian exports EUR 589 million, imports EUR 411 million). According to the UN COMTRADE data base in $2018^{18}$ the foreign trade reached a better level, the exports already surpassed USD 725 million (Figure 2) and the imports amounted to more than USD 700 million. The main items on the export list are iron and steel, copper, lead, mineral fuels, oil, distillation products, plastics, beverages, ores, rubber, oil seed, fruits, grain, paper, etc.

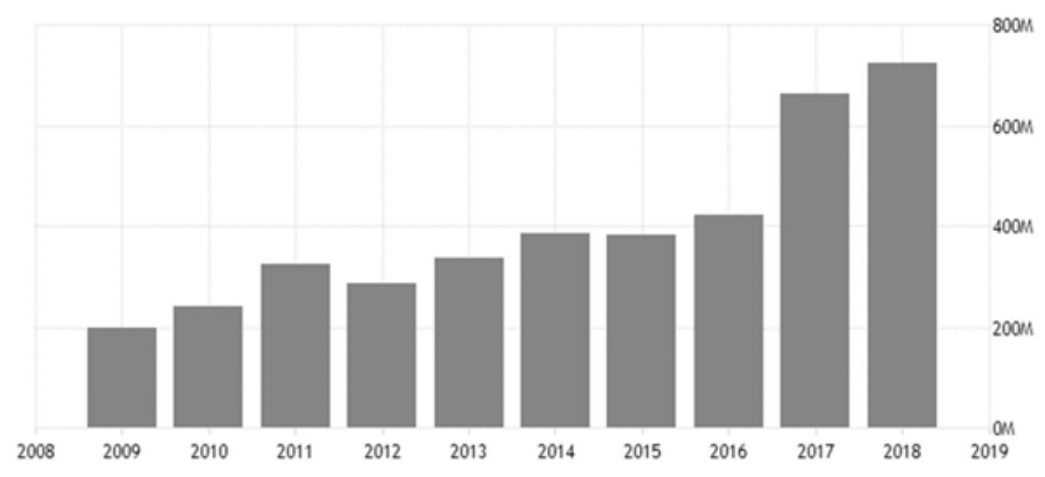

Source: $h$ ttps://tradingeconomics.com/serbia/exports/bulgaria, (10.09.2019)

Figure 2. Serbia Exports to Bulgaria (million USD)

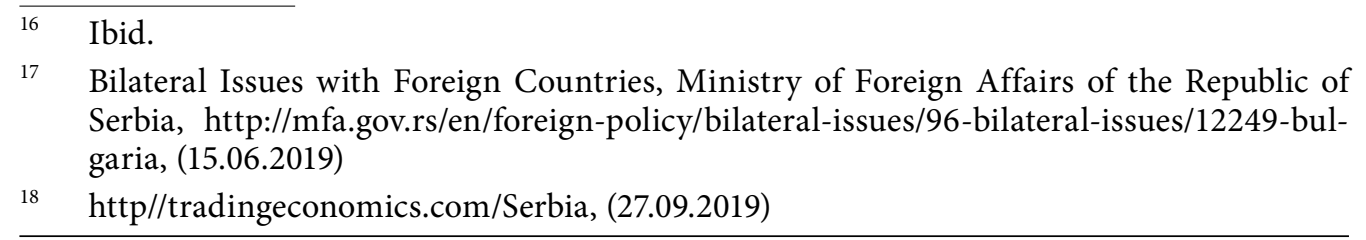


The Republic of Serbia also represents an important trading partner for the Republic of Bulgaria. Bulgaria's exports to Serbia fluctuate as shown on Figure 3, but in 2018 Serbia was among the top 15 Bulgaria's trading partners. Daniel Workman did a list showcasing 15 of Bulgaria's top trading partners, pointing out each import country's percentage of total Bulgarian exports. According to it Serbia ranks $14^{\text {th }}$ with total value of UDS 705 million $(1.9 \%)^{19}$. Bulgaria exports to Serbia mainly mineral fuels, oils, plastics, pharmaceutical products, ores, machinery, iron and steel, inorganic chemicals, glass and glassware, electrical equipment, etc.

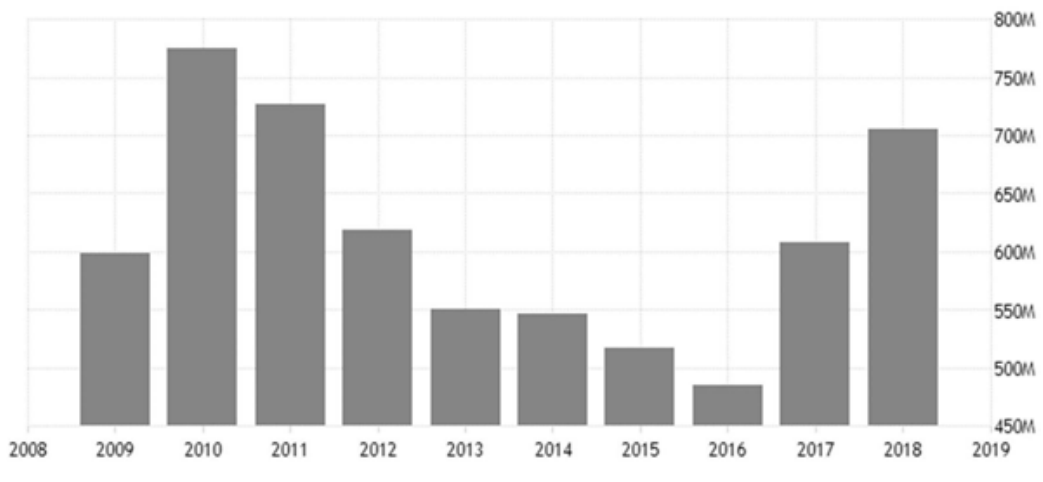

Source: https://tradingeconomics.com/bulgaria/exports/serbia, (26.09.2019)

Figure 3. Bulgaria Exports to Serbia (million USD)

The comparison of the FDI of Bulgaria and Serbia shows a slightly different picture. While Bulgaria can boast bigger turnover in foreign trade throughout the years, Serbia surpasses it in terms of FDI, especially during the last years with a volume of USD 4,1 billion (2018) from worldwide, while Bulgaria has attracted USD 2,6 billion (2018). Unfortunately, both countries do not have significant mutual investments. Due to this reason scarce information can be found in a limited number of resources. According to the UNCTAD FDI/TNC database Bulgarian investments in Serbia in 2014 are worth to USD 45 million and Bulgarian outward FDI stock to Serbia is equal to USD 87 million, while Serbian investments in Bulgaria amount to USD 46 million and the outward FDI stock to Bulgaria is equal to USD 113 million. ${ }^{20}$

The tendency in tourism is the opposite. Bulgaria has increased its annual revenues from tourism to USD 4.7 billion, while Serbia has more modest results of USD 1.7 billion in $2017^{21}$. During the same year approximately 9 billion tour-

19 Workman Daniel (2019): "Bulgaria's Top Trading Partners", http://www.worldstopexports. com/bulgarias-top-15-import-partners/, (10.06.2019)

20 World Investment Report (2018), UNCTAD, https://unctad.org/en/PublicationsLibrary/ wir2018_en.pdf

21 "Bulgarian Tourists in Serbia have Increased Threefold for the Last 10 Years", Novinite, 15.02.2018, https://www.novinite.com/articles/187964/Bulgarian+Tourists+in+Serbia+hav e+Increased+Threefold+for+the+Last+10+Years 
ists from all over the world visited Bulgaria while Serbia was visited by 1.5 billion tourists. The explanation can be found not only in the abundance of natural resources (Bulgaria has a lot of mountains and a beautiful seacoast) and geographical factors, but also in the fact that Serbia was a part of a bigger country (Yugoslavia) which has developed a touristic policy not in favor of Serbia. Anyway, Bulgaria has a lot of potential to move forward using the wealth of its spa and wellness resources. Serbia can also rely on the opportunities to develop mountain, cultural and conference tourism in the future.

Bulgarian tourists in Serbia have increased more than three times over the past ten years. In 2018 more than 490000 Bulgarians spent their holidays in Serbia, while 630000 Serbs visited Bulgaria. Bulgaria and Serbia have to continue their work on joint projects on cultural and historical heritage and on distant markets. 'The Wine Route' and 'The Road to the Roman Emperors' are among them according to Renata Pinja, Deputy Minister of Trade, Tourism and Telecommunications of Serbia. Bulgaria is among the top ten countries with the largest number of tourists visiting Serbia, said Maria Labović, Executive Director of the Country Tourism Organization. The most popular destinations for the Bulgarians are Belgrade, Niš, Novi Sad and the most preferred month for tourism is April. Serbian citizens visit mainly Bulgarian sea and ski resorts, while the high season is July-August ${ }^{22}$.

\section{Economic Cooperation on Regional European Programs and Projects}

Another aspect of the economic cooperation between Bulgaria and Serbia is their participation in regional programs and projects of mutual interest. BulgariaSerbia IPA Cross-border Cooperation Program is among the most useful EU programs. In the period 2007-2013 its goal was 'to boost territorial cohesion in the Bulgarian-Serbian cross-border region, as well as the competitiveness and sustainability of its development through co-operation in the economic, social and environmental spheres across administrative borders.' More than 100 successful projects have been reported at the end of the period, although it is questionable whether the projects really improve the well-being of the people in the region in a sustainable way. ${ }^{23}$

The next IPA CBC Bulgaria - Serbia 2014-2020 continues to develop cross-border cooperation through 'smart economic growth, environmental change adaptation and learning culture enhancement ${ }^{24}$. Within the frames of the cross-border 22 Ibid.

23 Stojadinović Miša., Vassileva Antoaneta (2019): "Overcoming the Balkan Stereotypes towards Regional Cooperation. Lessons Learnt", 9-10, in Stanar Dragan, Stoajadinović Miša (eds.) Geopolitical and Security Challenges in Southeastern Europe, Centar za strateške prognoze, Beograd

24 IPA CBC Bulgaria - Serbia, European Commission 2014-2020, European Commission, https://ec.europa.eu/regional_policy/en/atlas/programmes/2014-2020/ bulgaria/2014tc16i5cb007, (15.06.2019) 
cooperation between Bulgaria and Serbia for the period 2014-2020, the total value of the program was equal to EUR 34 million and the amount of EUR 29 million has been approved. The cross-border region includes the districts of Bor, Zaječar, Nišava, Pirot, Jablanica, Pčinj, Toplica in Serbia and Vidin, Montana, Sofia, Pernik, Vraca and Kyustendil in Bulgaria. ${ }^{25}$ One of the main reasons which make cross-border cooperation difficult is that from both sides there are underdeveloped regions which are far away from economic centers. 'This remote and mountainous border area has a beautiful landscape, almost virgin nature and offers significant opportunities for the development of tourism in the region. There are many natural parks and protected areas like the Belogradchik Rocks, the Magura Cave, the Rabisha Lake and the thermal springs in Kyustendil, Sapareva Banja, Vurshets or Rudartsi in Bulgaria, or the thermal springs on the Serbian side in Niška Banja, Soko Banja, Vranjska Banja and Zvonačka Banja. Environmental pollution, also a major problem of big towns and industrialized parts, does not exist in these rural areas ${ }^{26}$. That is why both countries have to increase their efforts in this direction because this will not only improve economy in this region, but it will also motivate population to stay in their homes.

Another European project that affects both countries is the EU strategy for the Danube region. The Danube region includes 14 countries, among which Bulgaria and Serbia. The Danube Strategy is carried out without allocation of new financial resources from the budget of the EU, without adopting special legislation and creating of new bureaucracy of the EU. It outlines a new form of cooperation between the partners, putting an emphasis on the building of closer synergies between the authorities at all levels and optimizing the activities through coordination of the existing financial instruments and policies.

The key objectives of the strategy are set out by its four pillars: to connect the Danube region, to protect the environment, to strengthen the region and to build prosperity. ${ }^{27}$ Eleven priority areas are translated into action through over 200 projects. The main idea is that 'each macro region has to be sustainable and has to include projects on a national as well as regional level'. The projects NEWADA, IRIS Europe I and II and FAIRway share a mutual goal for the improvement of the transport capacity of the river Danube and its flows. Despite the transparency of the transnational Danube program, it has been reported that EUR 263 million have been invested in different projects since 2011 up to now. The European Commission does not envisage financing of future projects. It will only support their self-financing and execution after 2020 .

${ }_{25}$ Milivojević Zoran et al. (2018): Izazovi manjinske politike u bilateralnoj i regionalnoj saradnji, Forum za etničke odnose, Beograd, 51-62

26 Koroutchev Rossen (2013): "The Bulgarian-Serbian Border Region: Problems and Perspectives", Klagenfurter Geographische Schriften, Institut für Geographie und Regionalforschung 29/2013, 128

27 EU Strategy for the Danube Region, European Commission, https://ec.europa.eu/regional_ policy/en/policy/cooperation/macro-regional-strategies/danube/ 
When the participation of both countries in the Danube strategy is discussed, projects in some very important areas cannot be neglected, for example, those closely connected with the priorities 'Promoting the principles of the sustainable development' and 'Trans-national research initiatives in support of the innovations'. They reflect the overall European concept for sustainable development, the Principles from Gothenburg and the Kyoto Protocol, so they can be easily adapted to the local policies and comprise various measures devoted to the increasing role of education for the promotion of the principles of the sustainable development. Here measures for the promotion of energy diversification and use of renewable energy sources, as well as implementation policies, can also be highly recommended. In this respect we can also add the measures aiming at the intensifying of trans border scientific and academic exchange, development of $\mathrm{R} \& \mathrm{D}$ centers and programs, projects for the support of the cooperation between the universities and the professional schools in European context, improving of the partnership between the educational institutions, the research and innovation centers, creation of partnership networks and stimulating of public private partnerships taking into consideration the heterogeneous character, the needs and the potential of the Danube region at all levels.

Investments have been planned for construction of renewable energy sources (hydroelectric and photovoltaic power plants), but up to now the results are not much obvious. Although the development of the initiatives differs in the separate countries, it is questionable if the Danube strategy is on the way to fulfil its objectives for the implementation of energy efficiency measures up to 2020. The benefits and the value added for Bulgaria and Serbia, and the Danube region will be evident in the increase of the energy independence of the region through construction of new and connection of functional networks for transit of natural gas, increasing the share of the energy produced by water power plants based on the specific potential of the region, building of a common energy market in the Danube region which includes new construction and modernization of existing intersystem connections of the grids of the countries and increasing of energy efficiency and decreasing the energy costs for the citizens and for the production plants.

There are some delicate issues which have to be solved with the EU and the USA in the light of the international sanctions towards Russia. Building the Turkish Stream pipeline on the Russian initiative is one of them. Serbia is one of the most important partners in this project, especially in its implementation from the Bulgarian to the Hungarian border. There is also an idea on behalf of Bulgaria for this project to become a kind of Balkan Stream pipeline which will deliver energy from different sources by construction of gas interconnectors with Turkey and Greece. It makes it an interesting initiative and Bulgaria and Serbia both can benefit from its development to diversify their energy sources ${ }^{28}$.

28 Данаилов Данаил (2014): Икономиките на Балканите, Издателски комплекс УНСС, София, 77-78 


\section{Conclusions and Recommendations}

Bulgaria and Serbia have opportunities to increase their mutual trade and investments and to deepen their cooperation in tourism, transport, energy, etc. The conclusion drawn from the analysis of the bilateral export and import patterns is that their potential is not fully realized. The exporting capacity needs to be further developed in order to provide better chances for participation in the global sourcing and value chains. The improvement of the overall political and economic relations of the two countries has been a subject of discussion during a joint meeting held in Niš between the deputy prime ministers of Serbia and Bulgaria. Both ministers have agreed to sign an interstate agreement on joint appearance in third markets with the aim of increasing exports of goods from Serbia and Bulgaria. They have expressed satisfaction with the fact that the economic cooperation between Serbia and Bulgaria is getting better and better, since the trade exchange in the previous year has exceeded EUR 1 billion and has a tendency of further growth. ${ }^{29}$

Foreign trade activities of Serbia are still oriented towards the countries of the Western Balkans and very much dependent on energy sources from Russia. The country can benefit from the economic relations with the rest of the members of the EU, including Bulgaria and to foster the export of innovative products with added value. A favorable opportunity for this is to take advantage of the pre-accession funds of the EU. It can utilize the European funding for building a modern infrastructure connecting all the countries in the Balkans. Stimulating tourism and creating incentives for the family business in tourist services could be a good source of income and contribution to the economic growth.

The analysis of the bilateral FDI flows between Bulgaria and Serbia shows that the scope of interest of the Bulgarian investors involves a limited number of sectors, which does not significantly affect the economic growth of the country. The potential of bilateral investment activities is underestimated. Despite the favorable investment regime in Bulgaria, including low and flat corporate income taxes (Bulgaria has Europe's lowest income and corporate tax, 10 per cent for individuals and businesses), significant challenges remain in attracting foreign direct investment. Rampant corruption at a massive scale ${ }^{30}$, lack of rule of law and very slow judiciary reform, expropriation and corporate raiding, still a very big share of the 'gray sector' in the economy, low productivity, and the constant changes of laws and regulations continue to hamper the country's investment climate and economic prospects. As far as Serbia is concerned, the

29 Improvement of political, economic relations between Serbia, Bulgaria, The Government of the Republic of Serbia, https://www.srbija.gov.rs/vest/en/138755/improvement-of-political-economic-relations-between-serbia-bulgaria.php, (26.09.2019)

30 Corruption is pointed out as one of the most problematic factors for doing business in Bulgaria in The Global Competitiveness Report (2016-2017), WEF, 130 
factors favorable to its economic growth include the economic reforms which it is undergoing as part of its EU accession process and IMF agreement, its strategic location, a relatively inexpensive and skilled labor force, and free trade agreements with the Russia, Belarus, Kazakhstan, Turkey and the group of countries that are members of the EU, EFTA and CEFTA. In order to be a reliable partner in the international economic relations and to attract FDI, it has to deal successfully with the bureaucracy and corruption ${ }^{31}$ and strengthen its democracy.

Touristic services between Bulgaria and Serbia are still not very well diversified. The opportunities that the river Danube provides are not used sufficiently. For example, joint cruises on the Danube can be organized, reaching the Black sea resorts of Bulgaria. The big share of the orthodox Christians in both countries creates possibilities for the increase of bilateral religious tours. The geographical proximity and the regular flights Sofia - Belgrade are good incentives for fostering of all the types of mutual tourism. Very closely connected with this issue is the construction of the Pan-European transport corridors which encompass road, rail and waterway routs. Serbia has almost completed the construction of the highway Belgrade-Niš-Dimitrovgrad which is a part of Corridor 10. Bulgaria has not finished its part Sofia-Kalotina, although it has access to European funds. The completion of the entire transport corridor will contribute to the region's connectivity and the development of business and tourism.

Joint efforts of the government, private sector and the academia should be made to develop interpersonal communication networks and to increase mutual awareness between the two countries that will promote trade and investment activities. These steps could involve, on behalf of the government - organization of fairs, exhibitions and more active engagement of embassies, on the behalf of the private sector - joint business initiatives, on the part of the academic circles - joint research of the potential areas of bilateral cooperation, participation in exchange programs not only to share experience, but also to discover a different culture and expand communication, what in its turn could lay grounds for new businesses and more successful economic relations.

$31 \quad$ Stankov Biljana, Markov Jasmina, Milošević Ivana (2015): FDI by Economic Activities and Investment Incentives in Bulgaria and Serbia, Management, 2015/77, 66, http://management.fon.bg.ac.rs/index.php/mng/article/view/59/47 


\section{Literature}

- "Bilateral Issues with Foreign Countries", Ministry of Foreign Affairs of the Republic of Serbia, http://mfa.gov.rs/en/foreign-policy/bilateral-issues/96bilateral-issues/12249-bulgaria, (15.06.2019)

- "Bulgarian Tourists in Serbia have Increased Threefold for the Last 10 Years", Novinite, 15.02.2018, https://www.novinite.com/articles/187964/Bulgarian+ Tourists+in+Serbia+have+Increased+Threefold+for+the+Last $+10+$ Years

- Данаилов Данаил (2014): Икономиките на Балканите, Издателски комплекс - УНСС, София, 77-78

- EU Strategy for the Danube Region, European Commission, https:// ec.europa.eu/regional_policy/en/policy/cooperation/macro-regional-strategies/danube/

- Improvement of political, economic relations between Serbia, Bulgaria, The Government of the Republic of Serbia, https://www.srbija.gov.rs/vest/ en/138755/improvement-of-political-economic-relations-between-serbiabulgaria.php, (26.10.2019)

- IPA CBC Bulgaria-Serbia, European Commission 2014-2020, https://ec.europa.eu/regional_policy/en/atlas/programmes/2014-2020/ bulgaria/2014tc16i5cb007 (15.06.2019)

- Koroutchev Rossen (2013): "The Bulgarian-Serbian Border Region: Problems and Perspectives", Klagenfurter Geographische Schriften, Institut für Geographie und Regionalforschung 29/2013, 128

- Лисоволик Ярослав, Чимирис Екатерина (2016): Сербия - ЕАЭС: перспективы интеграчии в рамках зоны свободной торговли. Рабочая тетрадь № 37/2016/, Российский совет по международным делам, Москва, 20

- Milivojević Zoran et al. (2018): Izazovi manjinske politike u bilateralnoj $i$ regionalnoj saradnji, Forum za etničke odnose, Beograd, 51-62

- Stankov Biljana, Markov Jasmina, Milošević Ivana (2015): "FDI by Economic Activities and Investment Incentives in Bulgaria and Serbia", Management, 2015/77, 61-77, http://management.fon.bg.ac.rs/index.php/mng/article/ view/59/47

- Stojadinović Miša, Vassileva Antoaneta (2019): "Overcoming the Balkan Stereotypes towards Regional Cooperation. Lessons Learnt", 9-10, in: Stanar Dragan, Stojadinović Miša (eds.): Geopolitical and Security Challenges in Southeastern Europe, Centar za strateške prognoze, Beograd

- "Tenth Meeting of the Accession Conference with Serbia at Ministerial level, Brussels, 27 June 2019", European Council, https://www.consilium.europa. $\mathrm{eu} / \mathrm{en} / \mathrm{press} /$ press-releases/2019/06/27/tenth-meeting-of-the-accession-conference-with-serbia-at-ministerial-level-brussels-27-june-2019/

- The Global Competitiveness Report (2016-2017), WEF, 130 
- The Global Competitiveness Report (2018), WEF, https://www.weforum.org/ reports/the-global-competitveness-report-2018

- Vassileva Antoaneta, Talović R.Violeta, Stojadinović Miša (2018): Geopolitical and Economic Challenges of the Globalized World, Lambert Academic Publishing, Saarbrucken, 274

- World Investment Report (2018), UNCTAD, https://unctad.org/en/PublicationsLibrary/wir2018_en.pdf

- Workman Daniel (2019): “Bulgaria’s Top Trading Partners", http://www.worldstopexports.com/bulgarias-top-15-import-partners/, (10.06.2019)

- https://www.cia.gov/library/publications/the-world-factbook/geos/ri.html, (26.09.2019)

- https://data.worldbank.org/indicator/NY.GDP.MKTP.KD.ZG?locations=BGRS, (27.09.2019)

- $\quad$ http://data.worldbank.org, (26.09.2019)

- https//tradingeconomics.com/Bulgaria, (27.09.2019)

- $\mathrm{http} / /$ tradingeconomics.com/Serbia, (27.09.2019) 
DOI: 10.5937/MegRev2004141V Pregledni naučni članak Primljen 03.05.2020. Odobren 12.07.2020.

\section{EKONOMSKI ODNOSI IZMEĐU BUGARSKE I SRBIJE: TRENUTNO STANJE I MOGUĆNOSTI}

Sažetak: Glavni cilj ovog rada je napraviti pregled trenutnog stanja ekonomskih odnosa između Bugarske i Srbije i dati neke preporuke za njihov budući razvoj. Analitički okvir zasnovan je na desk istraživanju ekonomske saradnje obe zemlje i na analizi nekoliko evropskih projekata u kojima učestvuju. Korišćeni su statistički podaci i informacije iz zvaničnih dokumenata vlada Bugarske i Srbije, kao i dokumenata Evropske unije. Autor nema za cilj da napravi samo komparativnu analizu, već da traži presek uzajamnih ekonomskih interesa obe zemlje. Nalazi istraživanja omogućavaju procenu dubine ekonomske saradnje između Bugarske i Srbije i daju osnove za zaključke o budućim izgledima njihovih ekonomskih veza.

Ključne reči: Bugarska, Srbija, ekonomska saradnja, spoljna trgovina, regionalni projekti 